\title{
INCENTIVE SYSTEMS IN PROJECT MANAGEMENT
}

\author{
S.A. Barkalov', barkalov@vgasu.vrn.ru, \\ V.N. Burkov², vlab17@bk.ru, \\ N.Yu.Kalinina1, kalinina@vgasu.vrn.ru, \\ T.V. Nasonova1, tnasonova@vgasu.vrn.ru \\ ${ }^{1}$ Voronezh State Technical University, Voronezh, Russian Federation, \\ ${ }^{2}$ V.A. Trapeznikov Institute of Control Sciences of Russian Academy of Sciences, \\ Moscow, Russian Federation
}

\begin{abstract}
Analysis of the current state of project management shows a significant increase in the number of projects implemented in the spheres of construction, public administration, energy, consulting, and digital technologies. Professional project management allows to effectively allocate responsibilities and responsibilities between project participants, save money and time, reduce risks. Understanding the importance of future development, the heads of organizations are increasingly using project management methods to create competitive advantages, and in the applied theory of management of organizational systems, more attention is paid to the teamwork of the organization's personnel.

An important task in the management of the project team is the formation of a system of incentives for its participants, whose task is to ensure the implementation of the project on time without additional budget expenditures. In order to maintain the motivation of project team members, individual and unified incentive schemes.

The disadvantage of individual incentive systems is, firstly, unequal conditions for encouraging different groups of performers, and secondly, the danger of manipulation, that is, deliberate distortion of information on the amount of work and costs transferred from the members of the project team. In order to exclude distortion of information and reduce tension in the project team, unified incentive schemes apply when the incentive mechanism is the same for all performers. Intermediate position is occupied by the group incentive schemes, when a number of project operations are divided into groups, for executors of each of which a unified incentive system is applied.

The article considers jumping unified stimulation systems, and the problem of choosing the optimal group incentive system is solved.

Keywords: project, team, cumulative unified incentive systems, group incentive schemes.
\end{abstract}

\section{Introduction}

Analysis of the current state of project management shows a significant increase in the number of projects implemented in the spheres of construction, public administration, energy, consulting, and digital technologies. Professional project management allows to effectively allocate responsibilities and responsibilities between project participants, save money and time, reduce risks. Understanding the importance of future development, the heads of organizations are increasingly using project management methods to create competitive advantages, and in the applied theory of management of organizational systems, more attention is paid to the teamwork of the organization's personnel.

The organization of teamwork is one of the fundamental principles of project management, which involves the formation of teams, the organization of their effective work and interaction with the goal of uniting and coordinating the efforts of all the performers involved in the project.

\section{The urgency and scientific significance of the issue}

The problems of the formation and functioning of teams are investigated in sociology - in the works of R.M. Andreeva, T.P. Galkina, A.V. Zhutkina, K. Levina, A.I. Prigogine; psychology in the works of V.V. Avdeeva, M.Yu. Gubieva, V.V. Isaeva, V.I. Kornienko, Yu.V. Sinyagin, K. Foppel, R. Chaldini, S. Tannenbaum, R. Beard, E. Salas; management - in the works of T.Yu. Bazarov, S.A. Barkalov [1, 2], P. Drakker, V.N. Mikheeva.

The results of the study of mathematical models of the formation and functioning of teams are 
reflected in the works of B.N. Burkov [3], D.A. Novikova [4, 5], A.G. Chkhartishvili, V. Holmstrom, J. Marshak, R. Radner. The current state of mathematical models of the formation and functioning of teams includes several research directions: assignment models that use, in the main, the optimization apparatus for solving the tasks of forming the composition of teams, the distribution of roles and the scope of work; game-theoretic models; simulation models; Reflexive models using the apparatus of the theory of reflexive games.

An important task in the management of project teams is the formation of incentive systems for project team members. In this case, it is necessary to take into account the specifics of the project activity $[1,2]$. To the conditions of the project it is unproductive to apply methods of stimulating current work. The task of the incentive system in project management is to ensure that the project is completed on time without additional budget expenditures. The calculation of incentive payments should be based on not only individual, but also team performance indicators.

When creating incentive systems for project team members, it is necessary to take into account the specifics of the project activity. To the conditions of the project it is unproductive to apply methods of stimulating current work. The task of the incentive system in project management is to ensure that the project is completed on time without additional budget expenditures. The calculation of incentive payments should be based on not only individual, but also team performance indicators.

In order to maintain the motivation of project team members, individual and unified incentive schemes are applied. The disadvantage of individual incentive schemes is, firstly, unequal conditions for encouraging different groups of performers, which can cause tension in the project team. Secondly, there is a danger of manipulation, that is, deliberate distortion of information on the amount of work and costs transferred from the members of the project team. In order to exclude distortion of information and reduce tension in the project team, unified incentive schemes apply when the incentive mechanism is the same for all performers. Intermediate position is occupied by group incentive schemes, when a number of project operations are divided into groups, for executors of each of which a unified incentive system is applied.

\section{Formulation of the problem}

Linear incentive systems use the linear function of the time of reduction of operations $h_{i}=\lambda \Delta_{i}$, where $\lambda$ - the standard for reducing the duration, which is uniform for all operations, $\Delta_{i}$ - is the planned decrease in the duration of the $i$-th operations. In the spasmodic incentive system, the premium $C$ to the performers of the operation does not depend on the magnitude of the reduction of the operation $\Delta_{i}$ and is the same for all transactions for which $\Delta_{i}>0$.

We consider linear cost functions of the form

$$
\varphi_{i}\left(\tau_{i}\right)=A_{i}-k_{i} \tau_{i}, i=\overline{1, n},
$$

where $\varphi_{i} \leq \tau_{i} \leq D_{i}, \quad i=\overline{1, n}$;

$$
h_{i}\left(\Delta_{i}\right)=\varphi_{i}\left(\tau_{i}^{0}\right)-\varphi_{i}\left(a_{i}\right) .
$$

For a linear cost function, the minimum costs for performing an operation are equal $B_{i}=A_{i}-k_{i} D_{i}$, and the maximum costs $N_{i}=A_{i}-k_{i} d_{i}$. Note that in the absence of stimulation, the duration of the $i$-th operation is $D_{i}, i=\overline{1, n}$.

Let the project be a sequential chain of $n$ operations. Let's assume that the operations are numbered in ascending order $k_{i}$, i. e. $k_{1} \leq k_{2} \leq \ldots \leq k_{n}$. The value $D_{i}$ defines the standard duration of the $i$-th operation, and the value $d_{i}$ - the minimum possible. It is necessary to build an optimal incentive system.

For the construction of an optimal individual incentive system, we determine such a number $j$, that is $\sum_{i=1}^{j-1}\left(D_{i}-d_{i}\right)<\theta \leq \sum_{i=1}^{j}\left(D_{i}-d_{i}\right)$, where $\theta=\sum_{i} D_{i}-T$ - required reduction in project duration. Operations $i=\overline{1, j-1}$ and operations $i=\overline{j+1, n}$ scheduled duration $\tau_{i}=d_{i}$. The planned duration of the operation $j$ is

$$
\tau_{j}=D_{j}-\theta+\sum_{i=1}^{j-1}\left(D_{i}-d_{i}\right) .
$$




\section{Краткие сообщения}

Determine the total amount of premiums.

The amount of bonuses for operations $i=\overline{1, j-1}$ is $h_{i}=N_{i}-B_{i}=k_{i}\left(D_{i}-d_{i}\right)$. The amount of bonuses for operation $j$ is $h_{j}=k_{j}\left(D_{j}-\tau_{j}\right)=k_{j} \Delta_{j}=k_{j}\left[\theta-\sum_{i=1}^{j-1}\left(D_{i}-d_{i}\right)\right]$. The amounts of bonuses for operations $i=\overline{j+1, n}$ are 0 . The total amount of premiums is

$$
H=\sum_{1}^{j-1} k_{i}\left(D_{i}-\tau_{i}\right)+k_{j}\left[\theta-\sum_{i=1}^{j-1}\left(D_{i}-d_{i}\right)\right]=k_{j} \theta-\sum_{1}^{j-1}\left(k_{j}-k_{i}\right)\left(D_{i}-d_{i}\right) .
$$

We construct an optimal unified incentive system.

Theorem 1. There is a unified system, such that the planned duration of operations for individual and unified incentive systems are the same, the standard $\lambda=k_{j}$, and the total amount of premiums is $k_{j} \theta$.

Evidence. Given a standard $\lambda$ the reduction in duration is possible for operations for which $k_{j} \leq \lambda$, that is, for operations for which the premium is not negative. It follows from condition (1) that $\lambda \geq k_{j}$, and hence the minimum $\lambda=k_{j}$. In this case, all operations for which $k_{i}<\lambda$ the planned duration is obtained $\tau_{i}=d_{j}$. If there are several operations for which $k_{i}=\lambda$, then we assume that the planned duration of all such operations except for the operation $j$, is equal to $d_{i}$, and the planned operation time $j$ is (2). The theorem is proved.

The difference between the total premiums of the unified and individual incentive systems is

$$
H_{y}-H=\sum_{1}^{j-1}\left(k_{j}-k_{i}\right)\left(D_{i}-d_{i}\right) .
$$

\section{Jumping Unified Incentive Systems}

Jumping unified incentive systems are characterized by the fact that premium $C$ is the same for all operations for which $\tau_{i j}<D_{i j}$ or $\Delta_{i j}>0$.

Let the premium value $C$ be given. In this case, the task is to shorten the duration of the project to the required value so that the number of operations with $\Delta_{i j}>0 \mathrm{~s}$ minimal. We show that this problem is reduced to a discrete problem of optimizing the network by cost. For a given value of $C$ the maximum reduction in the duration of the operation $(i, j)$ is equal to

$$
\eta_{i}=\min \left(\delta_{i} ; \frac{C}{k_{j}}\right) \text {. }
$$

Thus, the duration of each operation can take two values: the minimum value $D_{i j}$ with zero costs (premium) and the minimum value

$$
E_{i j}=D_{i j}-\eta_{i j}
$$

with costs (premium) $C$ for any operation.

A task. Determine the duration of operations so that the duration of the project was no more $(T-\theta)$, and the costs were minimal.

Discrete optimization problems belong to the class of complex problems of discrete optimization.

Consider the solution of this problem for aggregated networks. For this it is sufficient to consider a solution for a serial and parallel chain.

Decision. Order the operations in descending order $\eta_{i}$. We define the minimal number of operations such that the sum $\eta_{i}$ is at least $\theta$.

For independent (parallel) operations, the problem is solved more simply.

Solving problems for sequential and parallel operations, we get the dependence $S(T)$ of the premium value from $T$ for the whole aggregate project. Table. 1.

Example 1. Consider the network of Fig. 1 (operations are arcs). Data on transactions are shown in 
Table 1

\begin{tabular}{|c|c|c|c|c|c|c|}
\hline$(i, j)$ & $(0,1)$ & $(0,2)$ & $(0,3)$ & $(1,4)$ & $(2,3)$ & $(3,4)$ \\
\hline$d_{i j}$ & 1 & 1 & 1 & 2 & 1 & 3 \\
\hline$D_{i j}$ & 4 & 2 & 3 & 3 & 3 & 5 \\
\hline$\delta_{i j}$ & 3 & 1 & 2 & 1 & 2 & 2 \\
\hline
\end{tabular}

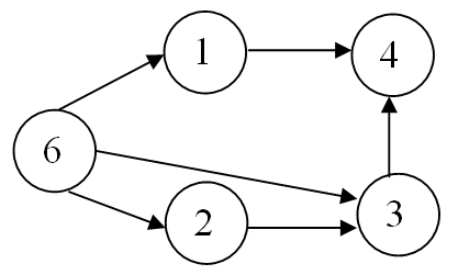

Fig. 1

We will be limited to consideration of $C$-systems.

1 step. We consider sequential operations $(0,2),(2,3)$. We have a dependence $S_{\text {aggr }}(\tau)$

\begin{tabular}{|c|c|c|c|c|}
\hline$\tau$ & 2 & 3 & 4 & 5 \\
\hline$S_{\text {aggr }}$ & $2 c$ & $c$ & $c$ & 0 \\
\hline
\end{tabular}

2 step. We consider parallel operations $(0,3)$ and aggregated $(0,3)$. We have a dependence $S_{03}\left(\tau_{03}\right)$

\begin{tabular}{|l|c|c|c|c|}
\hline$\tau$ & 2 & 3 & 4 & 5 \\
\hline$S$ & $3 c$ & $c$ & $c$ & 0 \\
\hline
\end{tabular}

3 step. We consider sequential operations $(0,1),(1,4)$. We have a dependence $S_{04}\left(\tau_{04}\right)$

\begin{tabular}{|c|c|c|c|c|c|}
\hline$\tau$ & 3 & 4 & 5 & 6 & 7 \\
\hline$S$ & $2 c$ & $c$ & $c$ & $c$ & 0 \\
\hline
\end{tabular}

4 step. Consider sequential operations aggregated $(0,3)$ and $(3,4)$. We have a dependence $S_{0}\left(\tau_{04^{\prime}}\right)$

\begin{tabular}{|c|c|c|c|c|c|c|}
\hline$\tau$ & 5 & 6 & 7 & 8 & 9 & 10 \\
\hline$S$ & $4 c$ & $4 c$ & $3 c$ & $c$ & $c$ & 0 \\
\hline
\end{tabular}

5 step. We consider parallel operations (0.4) and (0.4') (both aggregated). We have a dependence $S(T)$

\begin{tabular}{|c|c|c|c|c|c|c|}
\hline$T$ & 5 & 6 & 7 & 8 & 9 & 10 \\
\hline$S$ & $5 c$ & $5 c$ & $3 c$ & $c$ & $c$ & 0 \\
\hline
\end{tabular}

The described algorithm can be used to obtain lower bounds, transforming an arbitrary network into an aggregate.

\section{Group incentive schemes}

Consider the problem of choosing the optimal group incentive system in the following formulation. A plan was drawn up to shorten the duration of the project, in which the duration and operations are reduced by $\Delta_{i}$ having the cost function coefficients $K_{i}$ with a linear incentive system, the incentive rate is $\lambda \max K_{i}$, and the incentive fund is

$$
\Phi=\lambda \sum_{i} \Delta_{i}
$$

We will set the task of synthesizing the optimal group incentive system for a given number of groups $m<n$ (it is clear that when we have an individual incentive system $m=n$ ). Let the norms be defined

$$
\lambda_{1}<\lambda_{2}<\ldots<\lambda_{m}=\max _{i} K_{i}
$$

for each group. We denote by $Q_{j}$ the set of operations for which $K_{i} \leq \lambda_{j}$. 


\section{Краткие сообщения}

Theorem 2. The $j$-th group includes operations of the set $Q_{j} \backslash Q_{j-1}$ (by definition $Q_{0}=\varnothing$ ).

Evidence. Let there be an operation $S$ such that $K_{s} \leq \lambda_{j}$, but $S \in Q_{1}$, where $l>j$. The award to the performers of the operation $S$ is equal to $\lambda_{l} \cdot \Delta_{S}$. We transfer the operation $S$ to the group $j$. In this case, the premium will be $\lambda_{j} \cdot \Delta_{S}$, less than $\lambda_{l} \cdot \Delta_{S}$. The theorem is proved.

To solve the problem, we define $n+1$ vertex graph (network) with input 0 and output $n$ (Fig. 2).

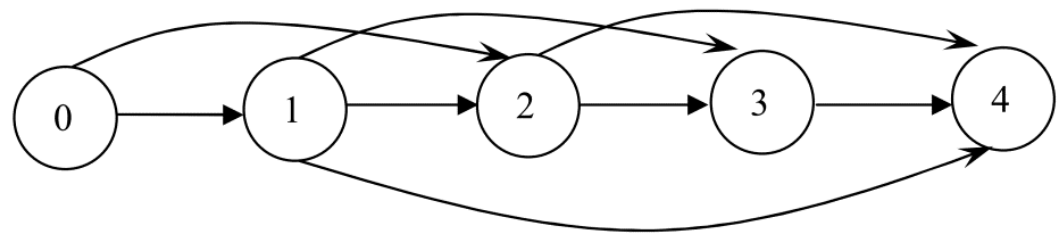

Fig. 2

Let $K_{i}$ be numbered in ascending order, that is, $K_{1} \leq K_{2} \leq \ldots \leq K_{n}$.

The arc $i, j$ of the graph reflects the fact that the operations $i+1, m, j$ belong to one stimulus group, and the incentive standard in this group is $K_{j}$. Note that any path in a graph joining an input with an output and having $m$ arcs determines uniquely the partition of operations into groups and the corresponding norms $\lambda_{j}$. The reverse is also true, to any partition of the executors of operations in the team into incentive groups there corresponds a certain path in the graph connecting the entrance with the exit.

Define the arc length $(i, j)$

$l_{i j}=K_{j} \sum_{S=i+1}^{j} \Delta_{s}$.

We show that $l_{i j}$ is equal to the fund for stimulating the group of operations $(i+1, m, j)$.

Indeed, the incentive standard for this group is $K_{j}$, and the total reduction in the durations of group operations is $\sum_{S=i+l}^{j} \Delta_{S}$.

Consequently, the length of any path from the $m$ arcs connecting the entrance to the exit is equal to the value of the incentive fund.

Task. Define $m$ - is the path (the path containing $m$ arcs) of minimal length.

This problem is a rather complex task of discrete optimization. Taking into account that the number of groups is usually small, the problem can be solved by brute force.

Example 2. The values $K_{i}, i=1,7$ are given in Table 2.

Let $m=3$. We fix the value $\lambda_{1}=K_{i}$ and solve the problem for operations $i+1, \ldots, n$ and two groups.

The search of all possible $\lambda_{1}$ and allows to determine the optimal system for для $m=3$.

Table 2

\begin{tabular}{|c|c|c|c|c|c|c|c|}
\hline$i$ & 1 & 2 & 3 & 4 & 5 & 6 & 7 \\
\hline$K_{i}$ & 1 & 3 & 4 & 7 & 8 & 10 & 12 \\
\hline$\Delta_{i}$ & 5 & 4 & 3 & 6 & 2 & 7 & 4 \\
\hline
\end{tabular}

We assume that the group can not include only one operation.

1 step. $\lambda_{1}=3$.

\begin{tabular}{|c|c|c|}
\hline$\lambda_{2}$ & 7 & 8 \\
\hline$\Phi$ & 246 & 247 \\
\hline
\end{tabular}

Optimum system $\lambda_{1}=3, \lambda_{2}=7, \Phi=246$.

2 step. $\lambda_{1}=4$.

\begin{tabular}{|c|c|}
\hline$\lambda_{2}$ & 8 \\
\hline$\Phi$ & 244 \\
\hline
\end{tabular}


Comparing 3 options, we find the optimal incentive system:

$\lambda_{1}=4, Q_{1}=(1,2,3)$;

$\lambda_{2}=8, Q_{2} \backslash Q_{1}=(4,5)$

$\lambda_{3}=12, Q_{3} \backslash Q_{2}=(6,7)$,

and a minimum incentive fund $\Phi=244$.

A similar problem can be solved for the $C$-stimulus system. Let the operations, the reduction values of their durations, and the coefficients $K_{i}$ be given. The size of the premium is obviously equal to

$C=\max K_{i} \Delta_{i}$

and the incentive fund $\Phi=C \cdot n$.

Let all operations be divided into $m$ groups and numbered in ascending order $K_{i} \Delta_{i}$, i. e. $K_{1} \Delta_{1} \leq K_{2} \Delta_{2} \leq \ldots \leq K_{n} \Delta_{n}$. Let the bonuses be determined $C_{1}<C_{2}<\ldots<C_{n}=C=\max K_{i} \Delta_{i}$.

We denote by $Q_{j}$ the set of operations for which $K_{i} \Delta_{i} \leq C_{j}$. Then it is obvious that

$$
C_{j}=\max _{i \in Q_{j}} K_{i} \Delta_{i},
$$

and the incentive fund is

$$
\Phi=\sum_{j} C_{j} N\left(Q_{j}, Q_{j-1}\right),
$$

where $N\left(Q_{j}, Q_{j-1}\right)$ number of operations in the $j$-th group.

The problem, like the previous one, reduces to determining the shortest $m$-paths in a graph with arc lengths

$l_{i j}=K_{j} \Delta_{j} \cdot(j-i)$.

With a small number of groups, the problem, like the previous one, can be solved by exhaustive search.

Example 3. Take the data of Example 2. Number of groups $m=3$.

1 step. Take the first group of operations $(1,2), C_{1}=12$.

We have two options for groups 2 and 3 . In the first variant, the second group $(3,5)$ with $C_{2}=16$, and the third $(4,6,7)$ with $C_{3}=70$. The incentive fund is

$\Phi=2 \cdot 12+2 \cdot 16+3 \cdot 70=266$.

In the second variant, the second group $(3,5,4)$ with $C_{2}=42$, and the third $(6,7)$ with $C_{3}=70$. The incentive fund is

$\Phi=2 \cdot 12+3 \cdot 42+2 \cdot 70=190$.

2 step. Take the first group of operations $(1,2,3), C_{1}=12$. There is only one option in the second group to include operations $(5,4)$ with $C_{2}=42$, but in the third operation $(6,7)$ with $C_{3}=70$. The incentive fund is

$\Phi=3 \cdot 12+2 \cdot 42+2 \cdot 70=260$.

Optimal is the option $(1,2,3),(5,4),(6,7)$ with the fund 260 .

In this case, the group $L$-system is more effective than the group $C$-system. However, we can cite problems in which the group $C$-system is more effective (for the same number of groups).

\section{Conclusion}

Group incentive systems occupy an intermediate place between individual systems and unified systems. They to some extent reduce the shortcomings of individual systems, as they generate competition both within groups and between groups and at the same time, as a rule, more effective than unified ones. The problem of constructing optimal group systems for arbitrary network graphs, and the development of effective algorithms for determining shortest paths with a fixed number of arcs are of interest. 


\title{
References
}

1. Barkalov S.A., Davydova T.E., Kalinina N.Yu., Kurnosov V.B. Kompetentnostnyy podkhod v upravlenii personalom: otsenka, obuchenie, komandoobrazovanie [Competence Approach in Personnel Management: Assessment, Training, Teambuilding]. Voronezh, Nauchnaya kniga Publ., 2010. 184 p.

2. Barkalov S.A., Kalinina N.Yu., Nasonova T.V. [The Tasks of Increasing the Level of Competence of the Organization's Personnel]. Economics and Management of Management Systems, 2017, no. 3.1 (25), pp. 110-116. (in Russ.)

3. Burkov V.N., Korgin N.A., Novikov D.A. Kak upravlyat' proektami: nauchno-prakticheskoe izdanie [Introduction to the Theory of Management of Organizational Systems]. Moscow, Librokom Publ., 2009. 264 p.

4. Burkov V.N., Novikov D.A. Matematicheskie modeli formirovaniya i funktsionirovaniya komand [How to Manage Projects: Scientific and Practical Edition]. Moscow, SYNTHEG - GEO Publ., 1997. $188 \mathrm{p}$.

5. Novikov D.A. Stimulirovanie $v$ organizatsionnykh sistemakh [Stimulation in Socio-Economic Systems]. Moscow, SINTEG Publ., 2003. 312 p.

Received 30 August 2018

\section{Удк 658.3}

DOI: $10.14529 /$ ctcr180415

\section{СИСТЕМЫ СТИМУЛИРОВАНИЯ В УПРАВЛЕНИИ ПРОЕКТАМИ}

\author{
С.А. Баркалов ${ }^{1}$, В.Н. Бурков ${ }^{2}$, Н.Ю. Калинина ${ }^{1}$, Т.В. Насонова ${ }^{1}$ \\ ${ }^{1}$ Воронежский государственный технический университет, г. Воронеж, Россия, \\ ${ }^{2}$ Институт проблем управления им. В.А. Трапезникова Российской академии наук, \\ е. Москва, Россия
}

Анализ современного состояния управления проектами показывает существенное увеличение количества проектов, реализуемых в сферах строительства, государственного управления, энергетики, цифровых технологий. Понимая важность будущего развития, руководители организаций применяют методы управления проектами для создания конкурентных преимуществ, а в прикладной теории управления организационными системами все большее внимание уделяется командной деятельности персонала организации.

Важная задача в управлении проектной командой - формирование системы стимулирования ее участников, задача которой - обеспечить выполнение проекта в срок без дополнительных расходов бюджета. В целях поддержания мотивации участников проектных команд применяются индивидуальные и унифицированные системы стимулирования.

Недостатком индивидуальных систем стимулирования является, во-первых, неравные условия поощрения различных групп исполнителей, а во-вторых, опасность манипулирования, то есть сознательного искажения информации об объемах работ и затратах, передаваемой от членов проектной команды. Для того чтобы исключить искажение информации и снизить напряженность в команде проекта, применяют унифицированнье системы стимулирования, когда механизм стимулирования один и тот же для всех исполнителей. Промежуточное положение занимают групповые системы стимулирования, когда множество операций проекта разбивается на группы, для исполнителей каждой из которых применяется унифицированная система стимулирования.

В статье рассматриваются скачкообразные унифицированные системы стимулирования, и решается задача выбора оптимальной групповой системы стимулирования.

Ключевые слова: проект, команда, объединенные унифицированные системы стимулирования, групповые системы стимулирования. 


\section{Литература}

1. Компетентностный подход в управлении персоналом: оценка, обучение, командообразование / С.А. Баркалов, Т.Е. Давыдова, Н.Ю. Калинина, В.Б. Курносов. - Воронеж: Научная книга, 2010. $-184 \mathrm{c}$.

2. Баркалов, С.А. Задачи повышения уровня компетентности персонала организации / С.А. Баркалов, Н.Ю. Калинина, Т.В. Насонова // Экономика и менеджмент систем управления. 2017. - № 3.1 (25). - C. 110-116.

3. Бурков, В.Н. Как управлять проектами: науч.-практ. изд. / В.Н. Бурков, Д.А. Новиков. М.: СИНТЕГ-ГЕО, 1997. - $188 \mathrm{c}$.

4. Новиков, Д.А. Математические модели формирования и функционирования команд / Д.А. Новиков. - М.: Изд-во физ.-мат. лит., 2008. - 184 с.

5. Новиков, Д.А. Стимулирование в организаиионных системах / Д.А. Новиков. - М.: СИНТЕГ, 2003. -312 c.

Баркалов Сергей Алексеевич, д-р техн. наук, профессор, декан факультета экономики, менеджмента и информационных технологий, зав. кафедрой управления строительством, Воронежский государственный технический университет, г. Воронеж; barkalov@vgasu.vrn.ru.

Бурков Владимир Николаевич, д-р техн. наук, профессор, главный научный сотрудник, Институт проблем управления им. В.А. Трапезникова Российской академии наук, г. Москва; vlab17@bk.ru.

Калинина Наталия Юрьевна, канд. техн. наук, доцент кафедры управления строительством, Воронежский государственный технический университет, г. Воронеж; kalinina@vgasu.vrn.ru.

Насонова Татьяна Владимировна, канд. техн. наук, старший преподаватель кафедры управления строительством, Воронежский государственный технический университет, г. Воронеж; tnasonova@vgasu.vrn.ru.

Поступила в редакцию 30 августа 2018 г.

\section{ОБРАЗЕЦ ЦИТИРОВАНИЯ}

Incentive Systems in Project Management / S.A. Barkalov, V.N. Burkov, N.Yu. Kalinina, T.V. Nasonova // Вестник ЮУрГУ. Серия «Компьютерные технологии, управление, радиоэлектроника». - 2018. - Т. 18, № 4. C. $152-159$. DOI: $10.14529 /$ ctcr 180415

\section{FOR CITATION}

Barkalov S.A., Burkov V.N., Kalinina N.Yu., Nasonova T.V. Incentive Systems in Project Management. Bulletin of the South Ural State University. Ser. Computer Technologies, Automatic Control, Radio Electronics, 2018, vol. 18, no. 4, pp. 152-159. DOI: $10.14529 / \operatorname{ctcr} 180415$ 